\title{
Use of conventional and satellite data for estimation of evapotranspiration spatial and temporal pattern
}

\author{
Piotr Struzik, Małgorzata Kępińska-Kasprzak \\ Institute of Meteorology and Water Management - National Research Institute, Podleśna 61, 01-673 Warsaw, Poland, \\ e-mail: piotr.struzik@imgw.pl,malgorzata.kepinska-kasprzak@imgw.pl
}

\begin{abstract}
Evapotranspiration values (ET) are crucial for agriculture where estimates of water reserves available for crops are the basis for scheduling the time and intensity of irrigation, yield prognoses, etc. Detailed evapotranspiration data are, therefore, of essential value. However, stations performing direct measurements of evapotranspiration are very scarcely distributed in Poland, and for this reason the interpolation of data is necessarily biased. Hence, evapotranspiration values are calculated using indirect methods (usually empirical formulas).

Data from geostationary meteorological satellites are used operationally for the determination of evapotranspiration with good spatial and temporal resolution (e.g. Land-SAF product). The study of the relation between evapotranspiration values determined with the use of satellite data and those calculated using the Penman-Monteith formula was performed for the study area in Poland. Daily values and cumulated (i.e. decadal, monthly and yearly) values were analysed to determine the quality and possible added value of the satellite product. The relation between the reference $E T$ and actual ET in two consecutive years was discussed, both for the whole test area and for individual stations, taking into account land use and possible water deficit in the root zone, represented by H-SAF (EUMETSAT Satellite Application facility supporting Operational Hydrology and Water Management) soil wetness index product. The differences are presented and discussed.
\end{abstract}

Keywords: reference evapotranspiration, actual evapotranspiration, remote sensing, Penman-Monteith method, Wielkopolska region

Submitted 22 July 2015, revised 7 March 2016, accepted 6 June 2016

\section{Introduction}

The second half of the $20^{\text {th }}$ century was a period of evident changes in climate conditions both on global and regional scales (IPCC 2007; Kundzewicz, Kowalczak 2008). Consequently, greater attention has been directed to issues related to droughts and water deficit, their causes, mitigation and response strategies. Strategies aiming to solve water shortage problems have become important elements of research programmes and policies throughout the whole of Europe. The water shortage problems have been addressed by, among others, the United Nations Convention to Combat Desertification in Countries Experiencing Serious Drought and/or Desertification, Particularly in Africa (UN 1994), and international legislation regulating the common framework for drought related actions (from the United Nations). The signatory states of the Convention are committed to prepare national action programmes to combat desertification and mitigate the effects of drought, incorporating, among other aspects, collection, analysis and exchange of information, scientific research, the technology of transfer, etc. The conclusions of analyses indicating a trend of increasing frequency of drought occur- rences (COM(2007)414 final; COM(2007)345 final; IPCC 2007; $\operatorname{COM(2008)875~final;~} \operatorname{COM}(2009) 147$ final) resulted in the publication of two European Parliament resolutions (2005/2049(INI); 2008/2074(INI)) and the Report from the Commission to the European Parliament and the Council (COM(2011)133). The report concerning drought management plans (COM(2008)875 final) includes recommendations on operational plans for drought risk management in order to effectively prevent and mitigate the impact of water scarcity and drought on the natural environment and economy.

Changes in climate conditions have also occurred in Poland. The currently observed warming was first noticed in the late 1970s and early 1980s (Kożuchowski, Żmudzka 2001; Żmudzka 2004; Michalska 2010). The most directly perceptible climate factor in the environment is air temperature. A statistically significant rise in air temperature was reflected in increased evaporation values in the early 1980s which showed upward trends for all synoptic stations in Poland (with the exception of one station in central Poland) (Kępińska-Kasprzak 2013). Because of the poor water resources, the prevalence of drainage in land reclamation systems and relatively low precipitation, particu- 
larly in agricultural areas of central Poland, knowledge of the actual water use for evapotranspiration is crucial for the monitoring of actual conditions, water resources planning, agrometeorological modelling and water use.

Evapotranspiration value is usually derived from empirical formulas which are only an approximation of real conditions. These equations allow for the determining of potential or reference evapotranspiration. In practice, the estimation of the evapotranspiration rate for a specific crop also requires the application of the proper crop coefficients $\left(k_{c}\right)$ to estimate actual crop evapotranspiration (Irmak, Haman 2003). However, as pointed out by S. Irmak in Evapotranspiration, the accurate estimation of evapotranspiration values is essential for the accurate determination of the components of hydrological balance. The knowledge of actual evapotranspiration values, therefore, is extremely important for the decision-making process and the adequate planning and management of water resources. The ability for real-time monitoring of changes in this parameter is of the utmost importance, especially in the context of agricultural drought monitoring. This can be accomplished with the application of remote sensing. The ongoing rapid development of remote sensing, easy access to information, constantly decreasing costs and near realtime data feeds, make satellite data a valuable source of input information for plant development stage assessment in operational services and also for agrometeorological models. Their additional advantage is information of high spatial resolution - at a range of 5-6 km (KępińskaKasprzak, Struzik 2011). In the case of mathematical equations, the input data are provided by meteorological stations and requires the application of interpolation for large areas due to the relatively sparse network of weather stations in Poland.

Solar radiation is the most important force modulating evapotranspiration. The previous ET products based on satellite data (e.g. MODIS, AVHRR) could not take into account the diurnal amount of solar radiation due to the low temporal availability of those data. In previous studies, solar radiation was measured on site (Dąbrowska-Zielińska et al. 2011) or determined from meteorological observations (Mu et al. 2013). Cloudiness is also an important factor limiting less frequent observations of vegetation states from polar orbit, when compared to geostationary orbit. The Land SAF ET product is the first such product using the temporal variation of solar radiation, due to use of a geostationary satellite. Good agreement between reference and actual ET in the periods and areas with favourable conditions is confirmation of the correct approach, with the model using satellite data as selected inputs.

Comparison of the Land-SAF actual ET product to the measured or evaluated actual ET in Poland is unfortunately difficult. Due to very inhomogeneous vegetation cover in the area of the satellite pixel $\left(25-30 \mathrm{~km}^{2}\right)$, ground measurements performed by the lysimeters could be not representative. In fact, such measurements are not performed in IMWM-NRI. The FAO recommended determination of actual ET (Allen et al. 1998), with the use of the crop $k_{c}$ coefficient, is almost impossible for the areas representing an entire satellite pixel. Such analysis could be performed, either with high resolution satellite data or over really large homogeneous areas.

The purpose of this paper is to study the feasibility and effectiveness of the simultaneous use of satellite data and ground-based measurements for a more precise assessment of spatial distribution of evapotranspiration for agricultural areas.

\section{Area of investigation}

The paper discusses the area of the Wielkopolska region, located in central-west Poland (Fig. 1). The area covers ca. $30000 \mathrm{~km}^{2}$ and has a population of ca. 3.4 million. Most of the analysed territory is low plain (25-264 $\mathrm{m}$ a.s.1.). Wielkopolska is located in the moderate climate zone with the significant influence of oceanic climate, the effects of which decrease towards the east. Compared to other Polish regions, Wielkopolska is characterised by a relatively early onset of spring and summer and a rather short winter. The mean annual air temperature is ca. $8.0^{\circ} \mathrm{C}$, with extremes of $+38^{\circ} \mathrm{C}$ and $-29^{\circ} \mathrm{C}$. The growing season lasts ca. 220 days and is one of the longest in Poland. Precipitation values are low and have a high temporal variability. The mean annual precipitation totals are highest in the western parts of the region, amounting to $550 \mathrm{~mm}$, with a decreasing tendency toward the east, where it drops locally below $500 \mathrm{~mm}$. The northern and southern parts of Wielkopolska are characterised by slightly higher precipitation values. In the central part of the region, the mean monthly precipitation totals oscillate from ca. $75 \mathrm{~mm}$ in July to a little above $20 \mathrm{~mm}$ in February. Snow cover lasts for ca. 40 days on average.

A very adverse climate characteristic for agriculture is represented by periods with little or no rains that last for several weeks, and which recur every 2-3 years. During summer these periods are accompanied by sunny and warm weather, which leads to the development of atmospheric drought followed by soil moisture loss and hydrological drought. Precipitation deficit is the cause of very poor water resources in the region. In eastern part of Wielkopolska, the total annual runoff value is lower than $60 \mathrm{~mm}$ in some areas. In Europe, lower values can only be 


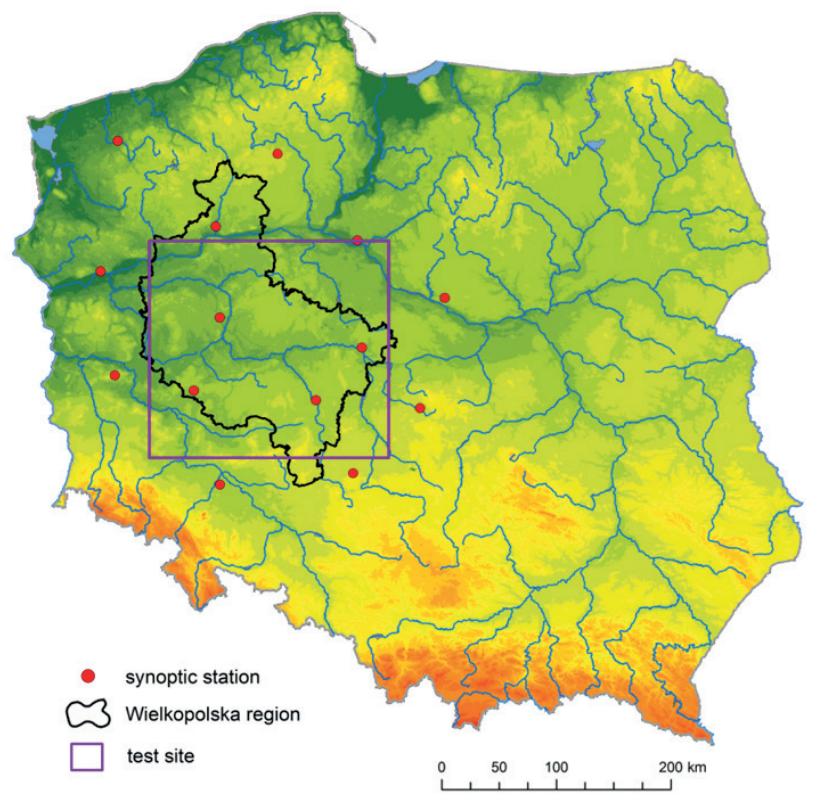

Fig. 1. The area of investigation

found in the steppe zone around the Black Sea and in the Hungarian Lowland.

Despite moderate natural conditions, the agriculture in Wielkopolska is very well developed compared to other regions of Poland. It is characterised by advanced agricultural technologies, high yields and up-to-date production equipment. A comprehensive assessment and the possibility of monitoring those climate elements that impact water relations, evaporation value in particular, are of crucial importance for the region.

\section{Research material and methods}

The analysis was based on daily data for the two-year period from 1 January 2012 to 31 December 2013. In Poland, the mean temperature in the year 2012 was $0.95^{\circ} \mathrm{C}$ higher than the average (calculated from the multiannual period 1971-2000). In the Wielkopolska region, the mean temperature was $0.5-1.0^{\circ} \mathrm{C}$ higher, depending on the location. Only three months (January, June and September) were normal and two (February and December) were slightly cooler than the average. The rest of the year was warmer, with an anomalously warm spring. The north part of Wielkopolska was wet and anomalously wet, the central and southern parts were close to the norm (based on Z. Kaczorowska's classification). In 2013 the average temperature was $0.7^{\circ} \mathrm{C}$ higher for the whole Poland. In the Wielkopolska region only March was extremely cold $\left(5.5^{\circ} \mathrm{C}\right.$ less than the average). During four months (January, February, April, September) the mean monthly temperature was close to the average. The remaining months were slightly warmer, and warmer than the average calculated from the period 1971-2000. Year 2013 was wet, with January, February, May, June and September extremely so.

Reference evapotranspiration $\left(E T_{0}\right)$ was calculated using information from 14 synoptic stations operated by the Institute of Meteorology and Water Management National Research Institute (IMWM-NRI), located in the Wielkopolska region and its surrounding area (Fig. 1). The input data included daily values of meteorological elements required to determine reference evapotranspiration, i.e. minimum and maximum air temperature, mean air humidity, wind speed and net radiation.

Reference evapotranspiration $\left(E T_{0}\right)$ is defined as the rate of evapotranspiration from a hypothetical reference crop (grass cover) with an assumed crop height of 0.12 $\mathrm{m}$, a fixed surface resistance of $70 \mathrm{~s} \mathrm{~m}^{-1}$ and an albedo of 0.23 , closely resembling the evapotranspiration from an extensive surface of green grass of uniform height, actively growing, well-watered, and completely shading the ground. The Penman-Monteith method, recommended by FAO and ICID (Allen et al. 1998), was used. An important feature of this method is its elasticity, i.e. the possibility to calculate the balance of the vertical flux of water at different time intervals (Lechnio 2005), including a 24-hour period. Also, the results obtained using the Penman-Monteith method are characterised by high reliability (Eitzinger et al. 2002).

The Penman-Monteith equation (Allen et al. 1998) is:

$$
E T_{0}=\frac{0,408 \Delta\left(R_{n}-G\right)+\gamma \frac{900}{t+273} u_{2}\left(e_{s}-e_{a}\right)}{\Delta+\gamma\left(1+0,34 u_{2}\right)}
$$

where: $E T_{0}-$ reference evapotranspiration $\left[\mathrm{mm} \cdot \mathrm{d}^{-1}\right]$; $R_{n}$ - net radiation $\left[\mathrm{MJ} \cdot \mathrm{m}^{-2} \cdot \mathrm{d}^{-1}\right] ; G-$ soil heat flux density $\left[\mathrm{MJ} \mathrm{m}^{-2} \mathrm{~d}^{-1}\right] ; t-$ mean daily air temperature at $2 \mathrm{~m}$ height $\left[{ }^{\circ} \mathrm{C}\right] ; u_{2}$ - wind speed at $2 \mathrm{~m}$ height $\left[\mathrm{m} \cdot \mathrm{s}^{-1}\right] ; e_{s}$ - saturation vapour pressure $[\mathrm{kPa}] ; e_{a}-$ actual vapour pressure $[\mathrm{kPa}] ; \Delta$ - slope of the saturation vapour-pressure curve $\left[\mathrm{kPa} \cdot{ }^{\circ} \mathrm{C}^{-1}\right] ; \gamma-$ psychrometric constant $\left[\mathrm{kPa} \cdot{ }^{\circ} \mathrm{C}^{-1}\right]$.

The soil heat flux $(G)$ is small compared to net radiation (Allen et al. 1998) and is very often omitted in the farther calculations (Kasperska-Wołowicz, Łabędzki 2004).

Reference evapotranspiration daily totals derived from the above formula for 14 weather stations were used to determine decadal (10-day period) and monthly $E T_{0}$ totals. These values allowed for the performance of detailed analysis of their annual variability and the spatial interpolation of the results.

Satellite remote sensing is the only method capable of providing wide-area coverage of environmental variables at economically affordable costs. The major difficulty in the use of remote sensing for the monitoring of the actual 
evapotranspiration $\left(E T_{a}\right)$ at regional and global scales is that the phase change of water molecules produces neither emission nor absorption of an electromagnetic signal (Keller et al. 2002). Therefore, the actual evapotranspiration process is not directly quantifiable from satellite observations. The simplest empirical methods are only applicable locally, where they were calibrated. The product generated operationally by EUMETSAT Land SAF represents complex deterministic models, which compute the different components of the energy budget (Fig. 2). The model is a simplified Soil-Vegetation-Atmosphere Transfer (SVAT) scheme that uses as its input a combination of remote-sensed data and atmospheric model outputs (Ghilan et al. 2011). The inputs based on remote sensing are LSASAF products: the Albedo (AL), the Downwelling Surface Shortwave Flux (DSSF) and the Downwelling Surface Longwave Flux (DSLF). Depending on the location of the pixel, different types of vegetation can share the area. A decomposition of the pixel surface is done by considering the fraction fully covered by vegetation and the remaining fraction of bare soil for each area of land cover. The considered smaller homogeneous entities (vegetation or bare soil) are called "tiles". The land cover types associated to tiles (grassland, crops, forests, bare soil, etc.), the respective coverage fraction and associated parameters are deduced from the ECOCLIMAP, a surface parameter global database at a $1 \mathrm{~km}$ resolution developed by METEO-France (Masson et al. 2003). It is well suited for use in SVAT schemes embedded in meteorological and climate models at all horizontal scales. Then, the set of equations of the model is solved for each tile before spatially averaging at the pixel level. They are available with the spatial resolution of the MSG SEVIRI instrument. The MET algorithm is an energy balance model aiming to compute, for each tile $\mathrm{i}$ in the considered pixel, the partition of net radiation $\left(R_{n i}\right)$, sensible heat flux $\left(H_{i}\right)$, latent heat flux $\left(L E_{i}\right)$ and heat conduction flux into the ground $\left(G_{i}\right)$ according to:

$$
R_{n i}-H_{i}-L E_{i}-G_{i}=0
$$

In the calculation of individual components of the model, satellite data are used for:

- LAI (Leaf Area Index) and DSSF are used for stomatal resistance determination;

- Albedo, DSSF and DSLF are used for determination of the net radiation at the surface;

- Soil heat flux is determined using parameterisation based on MSAVI (Modified Soil Adjusted Vegetation Index);

- Surface parameters (ECOCLIMAP) are determined with the use of the satellite data.

The calculated $E T_{a}$ is distributed in near real-time by the EUMETCast system. The covered area is a hemisphere visible from a 0 deg. geostationary satellite position, divided into continental products. Products are available in time steps of $30 \mathrm{~min}$ (instantaneous value) and 24 hours (cumulated value). The spatial resolution is a MSG/SEVIRI (Meteosat Second Generation/Spinning Enhanced Visible and InfraRed Imager) pixel, with a size of approx. 5-6 km over the area of Poland. The physical value represented by the product is the spatial distribution of actual evapotranspiration $E T_{a}$ (UN 1994). The validation performed by Land SAF shows that the model is able to reproduce the observed ET temporal evolution from the diurnal to annual time scales for the temperate climate zones: the mean bias is less than $0.02 \mathrm{~mm} / \mathrm{h}$ and the root-mean square error is between 0.06 and $0.10 \mathrm{~mm} / \mathrm{h}$ (EUMETSAT 2010).

The values of actual evapotranspiration are extracted operationally at IMWM-NRI for the whole area of Poland. In this study, the analysis is focused on the area located between latitudes $51^{\circ} 20^{\prime} \mathrm{N}$ and $53^{\circ} \mathrm{N}$ and longitudes $16^{\circ} \mathrm{E}$ and $19^{\circ} \mathrm{E}$. The area includes the entire Wielkopolska region, with the exception of its northernmost part. Daily totals of the actual evapotranspiration were calculated for this test site on a grid represented by MSG/SEVIRI radiometer resolution and individually for each synoptic station marked in Fig. 1.

The application of these methods resulted in daily, decadal and monthly series of total values for reference evapotranspiration and actual evapotranspiration for the analysed stations. This allowed for the determining of a linear relationship (correlation) between corresponding values of reference and actual evapotranspiration. The differences between reference and actual evapotranspiration values were also analysed, as well as their temporal and spatial distribution. The causes of any potential differences were also identified. Furthermore, relationships between given soil moisture values at different depths and values of reference evapotranspiration and actual evapotranspiration were examined.

Soil moisture (SM) analysis was based on data provided by EUMETSAT H-SAF (Satellite Application Facility in Support to Operational Hydrology and Water Manage-

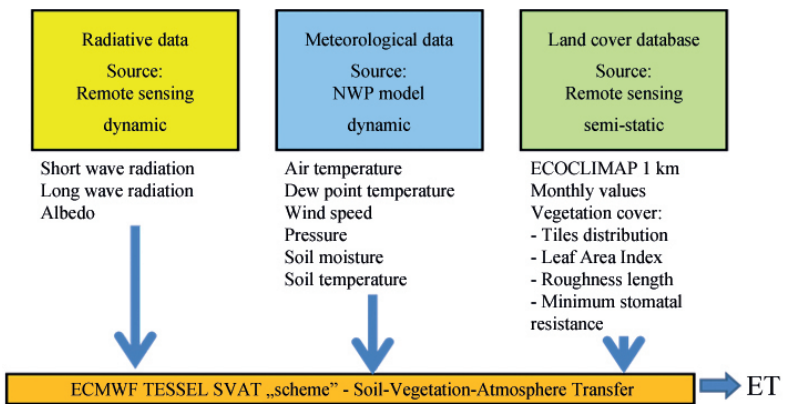

Fig. 2. Schematic diagram of Land-SAF evapotranspiration product 
ment) product. This product consists of a near real-time liquid root zone soil water content index from the assimilation of the global surface soil moisture index product (H-SAF H-16 large-scale surface soil moisture by radar scatterometer) into the ECMWF H-TESSEL Land Surface Model (Hydrology Tiled ECMWF Scheme for Surface Exchanges over Land). In the soil moisture assimilation system, the surface observation from the ASCAT (Advance Scatterometer) onboard Metop satellites is propagated towards the root region down to $2.89 \mathrm{~m}$ below the surface, providing estimates in $25 \mathrm{~km}$ horizontal resolution for 4 layers: 0-7 cm (SM1), 7-28 cm (SM2), 28-100 cm (SM3) and 100-289 cm (SM4) (EUMETSAT 2011). The Soil Wetness Index represents the saturation degree in percent [\%] for each layer. Validation performed by H-SAF in: France, Spain, Italy, Germany, Finland, Denmark, Luxembourg, shown on average: bias -0.043 , SD

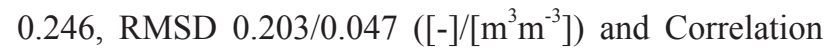
Coefficient 0.71 (EUMETSAT 2011).

The datasets used in this analysis have different spatial resolutions: $E T_{a}-5-6 \mathrm{~km}$, soil moisture $-25 \mathrm{~km}$, point calculation of $E T_{0}$ are based on meteorological parameters recorded at the station. The problem of resolution is minimized in the analysis performed for the whole area. In the analysis of temporal variation of $E T_{a}, E T_{0}$ and soil moisture, the nearest pixels of satellite products were used.

\section{Results}

Analysis of the linear relationship between corresponding values of reference and actual evapotranspiration showed that there is a very strong correlation between reference and actual evapotranspiration total values at the significance level of $\alpha=0.001$ (Table 1). However, $E T_{a}$ retrieved with the use of satellite data is generally lower. A much better agreement was obtained for Synop stations located far away from large cities. This is a consequence of a relatively large satellite pixel (approx. $6 \mathrm{~km}$ on this area) and tiles of land use types, used in the LandSAF product (Ghilain et al. 2011). In the case of urbanised and industrial terrain, evapotranspiration is significantly reduced. The Penman-Monteith method assumes the presence of grass cover over the whole area.

To avoid the effects of the Synop stations' locations unfortunately in many cases close to cities - spatial distribution of ET was generated for both reference evapotranspiration retrieved from ground observations and actual evapotranspiration retrieved with the use of satellite data. Interpolation was carried out on the Transverse-Mercator projection, making the estimation of the aerial volume of $E T$ for each day possible. Examples of ET spatial distribution, retrieved by two selected methods, are presented in Fig. 3. General agreement between these two datasets can be observed. The satellite product, due to the better resolution and incorporation of land use type in the retrieval method, has a more detailed structure.

The temporal course of the retrieved ET volume for the whole test site area is presented in Fig. 4. Good agreement of the two products can be observed. Actual $E T_{a}$ is slightly lower than reference $E T_{0}$, especially in dry periods.

The analysis of daily totals of reference and actual evapotranspiration showed that $E T_{a}$ values are lower than $E T_{0}$ values for all synoptic stations. Reversed cases were

Table 1. Correlation coefficient between daily, 10-day and monthly reference evapotranspiration and actual evapotranspiration (significance level $\alpha=0.001$ )

\begin{tabular}{|l|c|c|c|c|c|}
\hline \multicolumn{1}{|c|}{ Synoptic station } & $\begin{array}{c}\text { Station WMO } \\
\text { Index Number }\end{array}$ & Geographical location & daily & 10 -days & monthly \\
\hline Resko & 12210 & $15.409 \mathrm{E} 53.770 \mathrm{~N}$ & 0.96 & 0.99 & 1.00 \\
\hline Chojnice & 12235 & $17.526 \mathrm{E} 53.709 \mathrm{~N}$ & 0.96 & 0.99 & 0.99 \\
\hline Piła & 12230 & $16.742 \mathrm{E} 53.125 \mathrm{~N}$ & 0.94 & 0.97 & 0.99 \\
\hline Gorzów Wielkopolski & 12300 & $15.273 \mathrm{E} 52.738 \mathrm{~N}$ & 0.92 & 0.96 & 0.97 \\
\hline Toruń & 12250 & $18.590 \mathrm{E} 53.039 \mathrm{~N}$ & 0.92 & 0.94 & 0.97 \\
\hline Poznań & 12330 & $16.835 \mathrm{E} 52.417 \mathrm{~N}$ & 0.93 & 0.96 & 0.98 \\
\hline Płock & 12360 & $19.721 \mathrm{E} 52.587 \mathrm{~N}$ & 0.95 & 0.97 & 0.98 \\
\hline Koło & 12345 & $18.657 \mathrm{E} 52.200 \mathrm{~N}$ & 0.95 & 0.96 & 0.98 \\
\hline Zielona Góra & 12400 & $15.521 \mathrm{E} 51.925 \mathrm{~N}$ & 0.92 & 0.94 & 0.97 \\
\hline Leszno & 12418 & $16.536 \mathrm{E} 51.823 \mathrm{~N}$ & 0.96 & 0.98 & 0.99 \\
\hline Kalisz & 12435 & $18.076 \mathrm{E} 51.776 \mathrm{~N}$ & 0.85 & 0.87 & 0.90 \\
\hline Łódź & 12465 & $19.401 \mathrm{E} 51.723 \mathrm{~N}$ & 0.92 & 0.94 & 0.96 \\
\hline Wrocław & 12424 & $16.901 \mathrm{E} 51.103 \mathrm{~N}$ & 0.95 & 0.97 & 0.99 \\
\hline Wieluń & 12455 & $18.555 \mathrm{E} 51.207 \mathrm{~N}$ & 0.91 & 0.93 & 0.96 \\
\hline
\end{tabular}



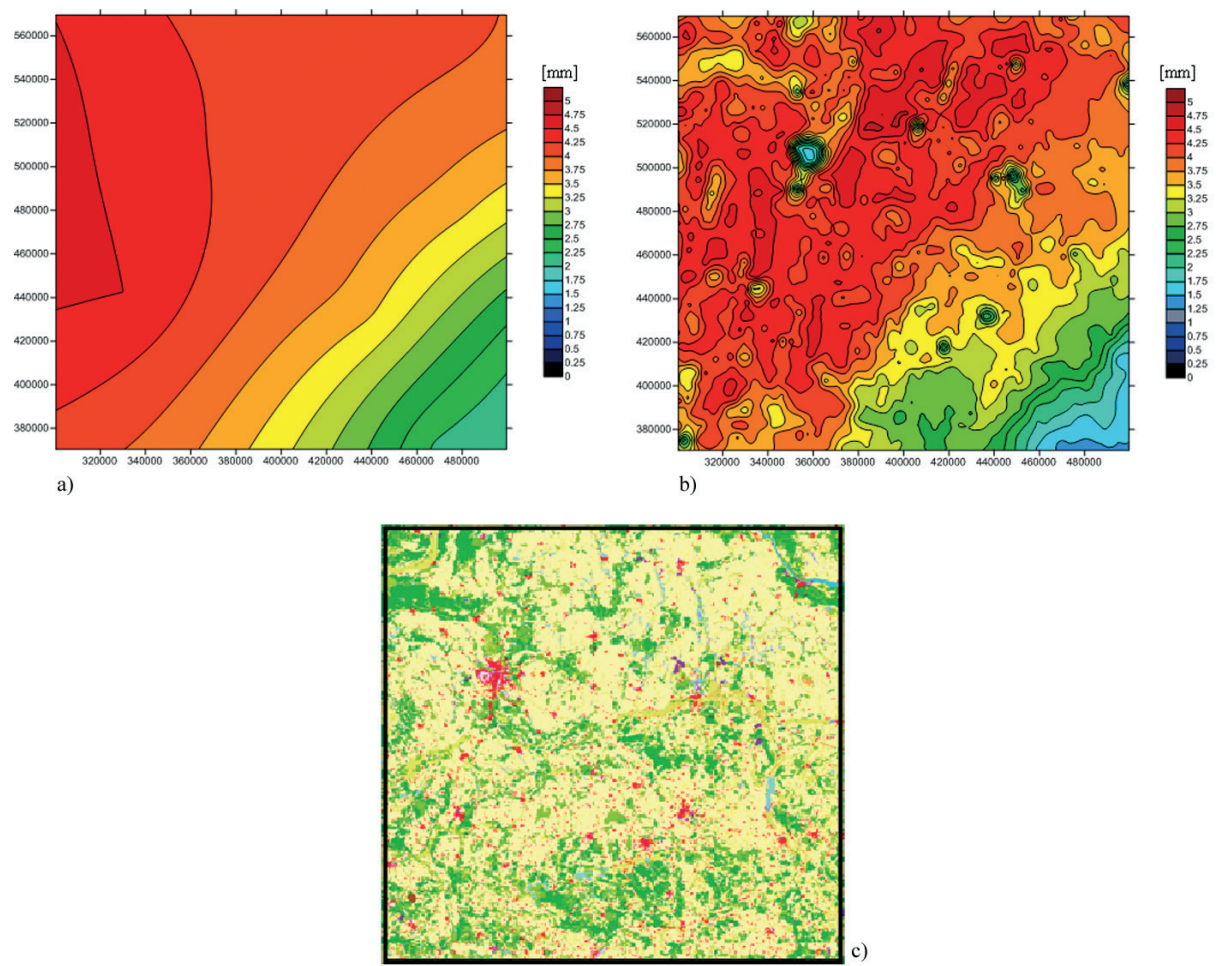

Fig. 3. Example of ET spatial distribution retrieved for a selected test site in the Wielkopolska region - 11.06.2013, (a) ET spatial distribution retrieved by the Penman-Monteith method, (b) from Land-SAF satellite product, (c) CORINE land cover for comparison

noted mostly in winter (November to mid-March) but are among only a few exceptions, since generally, in the cold season, $E T_{0}$ daily totals were higher than $E T_{a}$. This is especially well seen at the periods with frozen soil, when Land SAF products taking into account liquid water available in the root zone is significantly, sometimes quickly, reduced (even to zero value). In the winter time, during prolonged negative temperatures, both of the two upper layers are frozen, leading to a decrease of SM1 and SM2 parameters in affected areas. Mapping the deepness of frozen soil is of additional value for those products.

Consequently, the decadal evaporation totals show that $E T_{0}$ values are higher than $E T_{a}$ in almost all cases (sample comparison Fig. 5). The exceptions occurred in the first and third decades of December 2013, when $E T_{0}$ values were lower than $E T_{a}$ at three stations. This, however,

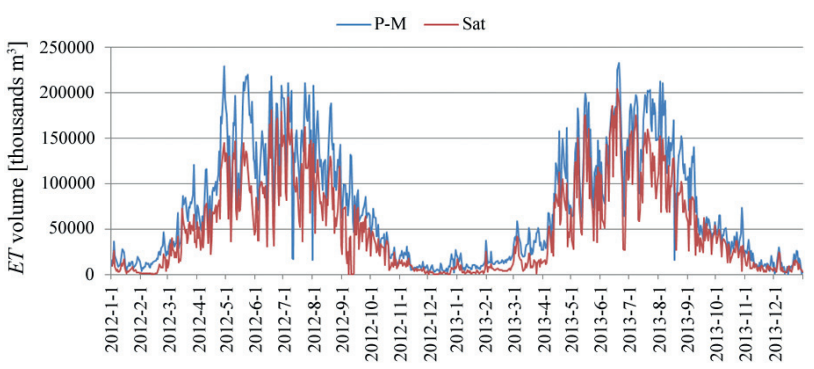

Fig. 4. Volume of $E T$ [thousands of $\mathrm{m}^{3}$ ], for the whole area of the test site determined from interpolated $E T_{0}$ by the PennmanMonteith method from ground observations (P-M) and $E T_{a}$ from Land-SAF satellite product (Sat) accounts for only $0.4 \%$ of all decades in the 2012-2013 period at the analysed 14 stations. The monthly totals of $E T_{0}$ and $E T_{a}$ indicate higher $E T_{0}$ values with the exception of one case noted at the Gorzow Wielkopolski station (December 2013).

The highest differences between $E T_{0}$ and $E T_{a}$ values were observed at all stations in the period from April to mid-September, i.e. during growing season. Table 2 shows a correlation between $E T_{0}$ and $E T_{a}$ in growing seasons in the analysed period of 2012-2013.

The growing season in 2013 is characterised by a slightly higher correlation between $E T_{0}$ and $E T_{a}$ than in 2012 season. This probably resulted from the fact that the growing season in 2013 was wetter due to higher precipitation. The correlation for both growing seasons, strong at significance level of $\alpha=0.001$ for the majority of stations, shows, however, a slightly weaker relationship be-

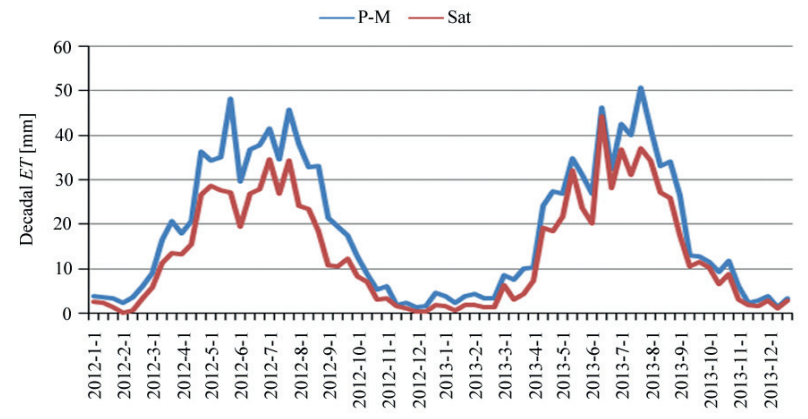

Fig. 5. Diagram of 10-day totals of $E T_{0}(\mathrm{P}-\mathrm{M})$ and $E T_{a}$ (Sat) for Leszno station 
Table 2. Correlation coefficient between reference evapotranspiration and actual evapotranspiration during growing seasons (significance level $\alpha=0.001$ )

\begin{tabular}{|l|c|c|c|}
\hline \multicolumn{1}{|c|}{ Synoptic station } & $2012-2013$ & 2012 & 2013 \\
\hline Resko & 0.90 & 0.87 & 0.93 \\
\hline Chojnice & 0.92 & 0.89 & 0.94 \\
\hline Piła & 0.85 & 0.82 & 0.88 \\
\hline Gorzów Wielkopolski & 0.81 & 0.75 & 0.86 \\
\hline Toruń & 0.81 & 0.75 & 0.87 \\
\hline Poznań & 0.82 & 0.77 & 0.87 \\
\hline Płock & 0.88 & 0.88 & 0.89 \\
\hline Koło & 0.87 & 0.83 & 0.93 \\
\hline Zielona Góra & 0.81 & 0.73 & 0.89 \\
\hline Leszno & 0.90 & 0.87 & 0.94 \\
\hline Kalisz & 0.67 & 0.66 & 0.76 \\
\hline Łódź & 0.82 & 0.78 & 0.88 \\
\hline Wrocław & 0.88 & 0.84 & 0.92 \\
\hline Wieluń & 0.81 & 0.79 & 0.85 \\
\hline
\end{tabular}

tween $E T_{0}$ and $E T_{a}$ during growing seasons than during an entire calendar year (see Table 1). This is explained by atmospheric droughts and water shortages noted in Wielkopolska during growing seasons, particularly in the June - September period.

The analysis of outliers gives the most interesting results. The lowest value of correlation coefficient was found for the areas of Kalisz (WMO Station Index No. 12435), and Wielun (WMO Station Index No. 12455). The location of Synop stations and the nearest MSG/SEVIRI pixel used for the retrieval of $E T_{a}$ in the satellite method overlaid on a CORINE Land Cover map is shown in Fig. 6. In the case of the Kalisz area, the Synop station is located within a large city area, unfortunately, and the nearest SEVIRI pixel covers mainly urbanised and industrial areas. This is the source of significant differences between reference and actual ET (Fig. 7), especially during high growing season.

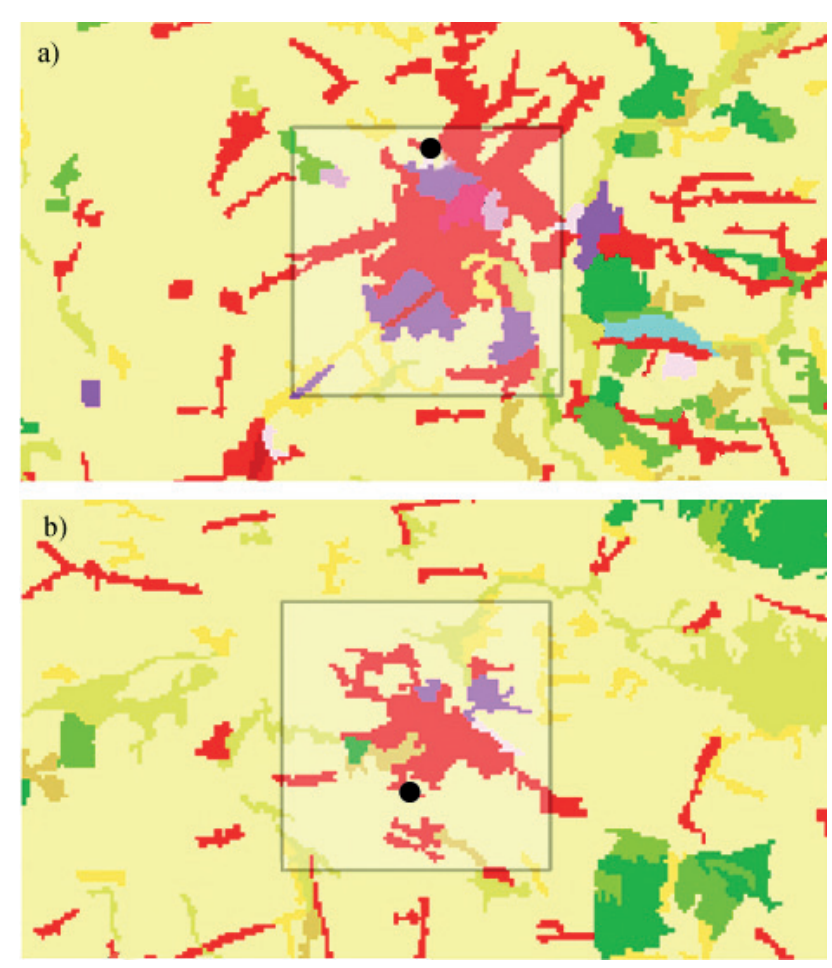

Fig. 6. Location of Synop stations and MSG/SEVIRI pixel (box), used for retrieval of ET, overlaid on CORINE Land Cover map: (a) Kalisz (WMO Index No. 12435), (b) Wieluń (WMO Index No. 12455); Red and blue - urbanised and industrial areas; green - forests; yellow to light brown - agricultural land and pasture; - Synop station localization

All situations with a soil wetness index below $40 \%$ are well correlated with reduced actual $E T_{a}$ and a larger difference between reference and actual evapotranspiration. The winter case of low soil moisture index is related to frozen ground and the absence of liquid water.

For the second Synop station, located in the Wielun area, a better agreement of reference and actual ET was found. The area covered by the nearest SEVIRI pixel also contains an urbanised area, but agricultural land and some forest are also present. The most interesting periods are those when the differences are larger. When analysing the temporal

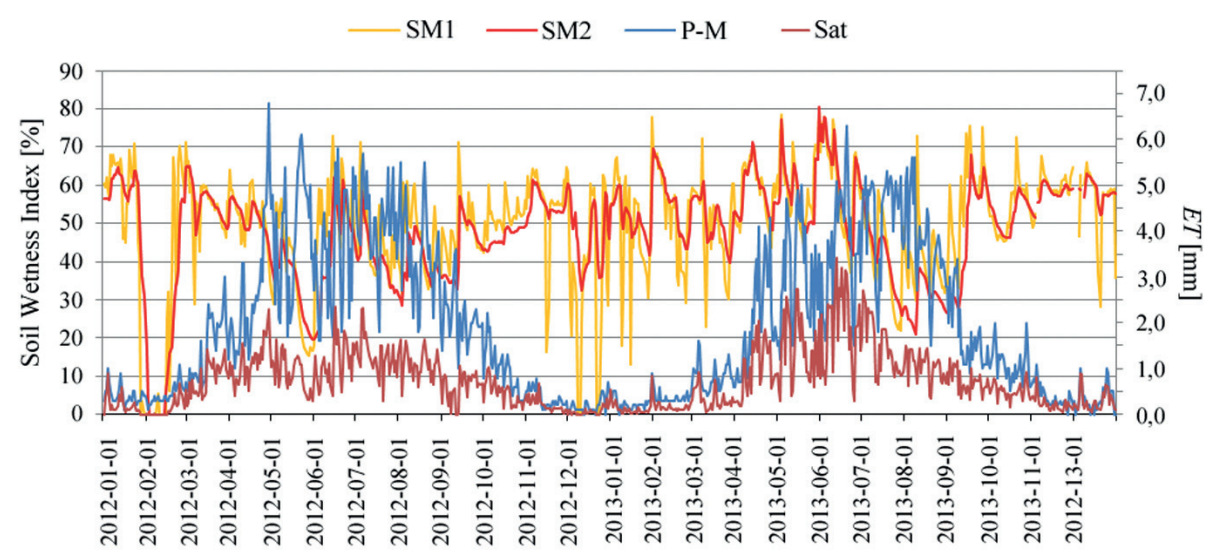

Fig. 7. Diagram of $E T_{0}$ retrieved by the Penman-Monteith (P-M) and $E T_{a}$ from LandSAF ET product for the Kalisz area; Added $\mathrm{H}-\mathrm{SAF}$ soil moisture for 0-7 cm layer (SM1) and for 7-28 cm layer (SM2) 


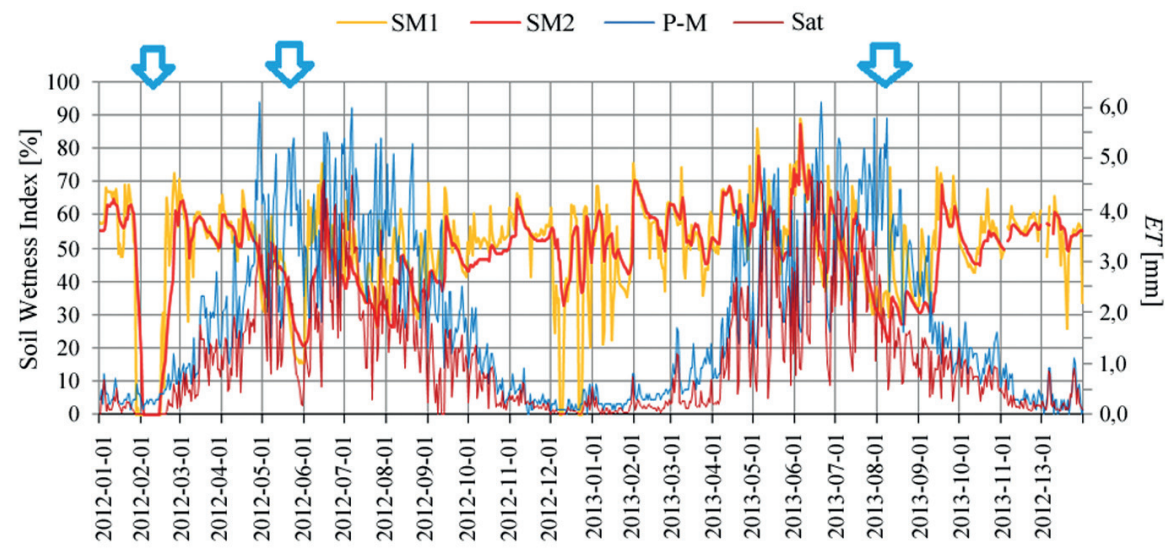

Fig. 8. Diagram of $E T_{0}$ retrieved by the Penman-Monteith (P-M) formula and $E T_{a}$ from Land-SAF product for the Wielun area; Added H-SAF soil moisture for 0-7 cm layer (SM1) and for 7-28 cm layer (SM2); Periods with a decreased amount of liquid water in root zone are indicated by arrows

course of soil moisture in the upper two layers: $0-7 \mathrm{~cm}$ and 7-28 cm, significant drops of SM can be found in: February 2012, May 2012, August 2012 and August 2013 (Fig. 8).

Finally, the benefits of a good spatial resolution of $E T_{a}$ determined with the use of satellite data are illustrated. The annual amount of evapotranspiration was calculated for the analysed years of 2012 and 2013, using Land SAF ET products for each 30 minutes. The results are presented in Fig. 9. At first sight, they are similar for both years. Areas with large water reservoirs, like Szczecin Estuary and Lake Łebskie, are excluded from the analysis. Generally, the lowest values are recorded for urbanised areas, medium values are observed for large forest complexes, especially coniferous forest, and the largest values are recorded for agricultural areas. The difference in the annual amount of evapotranspiration between years 2013 and 2012 is presented below (Fig. 9). Significantly higher values were observed for 2013 in regions where drought is frequently observed. These regions cover parts of Wielkopolskie, Łódzkie, Dolnośląskie and Lubuskie and the eastern part of Lubelskie. In these regions annual ET was $60-85 \mathrm{~mm}$ lower in 2012, when compared to 2013.

\section{Conclusions}

The values of reference evapotranspiration $\left(E T_{0}\right)$ calculated using the Penman-Monteith method and actual evapotranspiration $\left(E T_{a}\right)$ derived using the satellite data showed a very strong correlation at the $\alpha=0.001$ significance level, and very similar daily, and consequently, decadal and monthly values.

Generally, daily, decadal and monthly totals of reference evapotranspiration are higher than the corresponding values of actual evapotranspiration, with a few exceptions during the winter season when $E T_{0}$ values are lower than $E T_{a}$. The period during which $E T_{0}$ values are significantly higher than $E T_{a}$ is growing season. This is due to the fact that the Penman-Monteith method assumes no shortage of soil water in the reference surface. However, in the analysed area, growing seasons are periods characterised by a precipitation deficit and relatively high air temperatures, which lead to atmospheric droughts and a reduction of evapotranspiration due to soil water content depletion.

Large differences between $E T_{0}$ and $E T_{a}$ also result from different land use in areas for which evapotranspiration totals are calculated. The Penman-Monteith method deter-
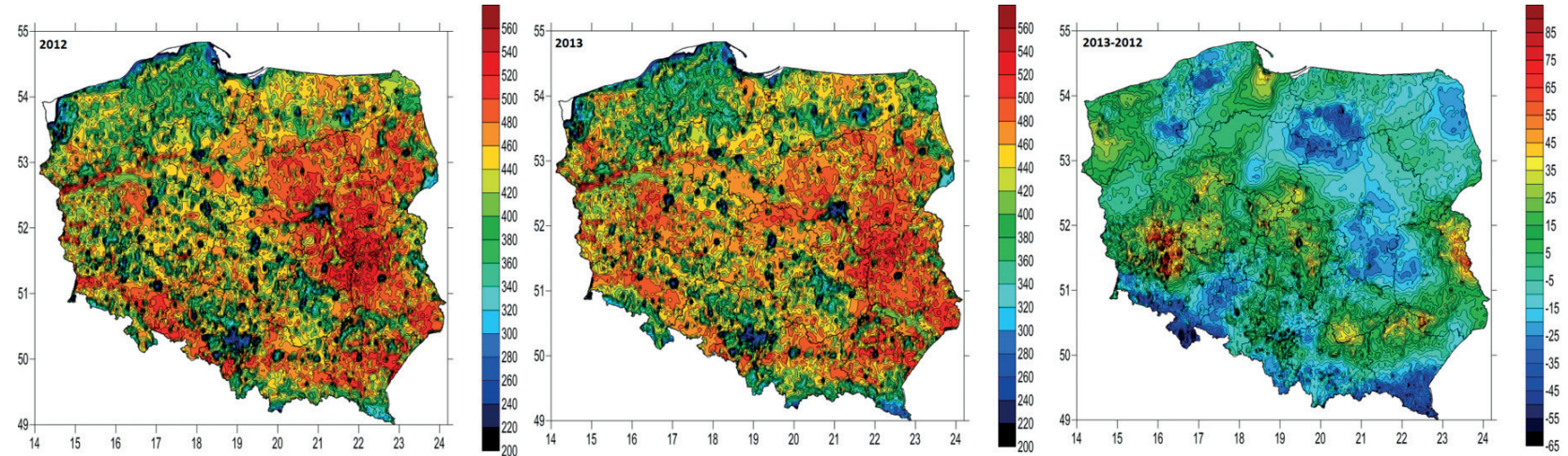

Fig. 9. Spatial distribution of annual amount of actual evapotranspiration [mm] determined with the use of satellite data: years 2012 (left), 2013 (middle) and the difference between 2013 and 2012 (right) 
mines evapotranspiration from a surface covered by green grass of uniform height $(0.12 \mathrm{~m})$. The satellite product, on the other hand, by including data from the land cover base, provides a much better and more realistic representation of field conditions in comparison with the reference evapotranspiration.

As indicated in the introduction, the accurate estimation of evapotranspiration values is essential for agricultural science and practice, hydrology and water management. In recent years, the practice in all these branches of science and decision-making processes has been based on data calculated from equations, most frequently using the Penman-Monteith formula, as far as evapotranspiration values are concerned. However, as demonstrated in this paper, the differences between the values of reference evapotranspiration (calculated using the Penman-Monteith method) and actual evapotranspiration (derived from the satellite product) can be significant. In the case of the analysed Wielkopolska region, the total magnitude of the differences in consecutive days for the entire area translates into thousands of cubic metres (see Fig. 4). The information on the amount of the evapotranspiration forms some of the most critical input data for further calculations of climatic water balance (CWB), which is calculated as the difference between the precipitation and the reference evapotranspiration (Labędzki, 2006). Climatic water balance is used for the assessment of water deficits or surpluses at different areas (Bac, Rojek 1979; Kuźniar 2010). Therefore, CWB is a basic indicator of drought, especially at agricultural areas (Labędzki 2006). The monitoring of changes in CWB values provides basic information for agrometeorological services and regional water bodies and allows for more proper water management. The problem takes on particular significance in regions affected by water deficit. Because the values of actual evapotranspiration derived from the "Evapotranspiration" product are available in near real-time and meteorological conditions do not affect satellite images, and taking into account the high spatial differentiation of evapotranspiration, the application of satellite data for evapotranspiration assessment in catchment areas appears to be the most efficient and economically optimal method. Work on perfecting the algorithm is still in progress and we can expect that future versions of the "Evapotranspiration" product will provide estimates that are even closer to the actual evapotranspiration values.

The presented $E T_{0}-E T_{a}$ relationships and the soil moisture retrieved by the H-SAF product showed interesting relationships, especially for the soil wetness index in the upper two layers of soil. Further investigation is recommended, taking into account the sensitivity of the H-SAF product to drought conditions on different land surface types (e.g. dense vegetation).

\section{Acknowledgements}

All work presented in this paper was carried out within the COST Action ES1106 Assessment of EUROpean AGRIculture WATer use and trade under climate change (EURO-AGRIWAT). The main objective of the Action is to deliver integrated methodologies and databases for the European-wide assessment of water use and trade associated to key food and energy crops at different spatial scales under current and future climate conditions. The paper presents the possibility of using satellite data as the information source for evapotranspiration values, which is one of the essential forms of data required for climatological and hydrological analysis.

\section{Bibliography}

2005/2049(INI), Resolution on Winning the Battle Against Global Climate Change, The European Parliament, EURLex, Brussels

2008/2074(INI), European Parliament Resolution of 9 October 2008 on Addressing the challenge of water scarcity and droughts in the European, The European Parliament, EURLex, Brussels

Allen R.G., Pereira L.S., Raes D., Smith M., 1998, Crop evapotranspiration. Guidelines for computing crop water requirements, FAO Irrigation and Drainage Paper, 56, 300 pp.

Bac S., Rojek M., 1979, Meteorology and climatology, (in Polish), PWN, $276 \mathrm{pp}$.

$\operatorname{COM}(2007) 414$ final, Communication from the Commission to the European Parliament and the Council. Addressing the challenge of water scarcity and droughts in the European Union, Commission of the European Communities, EURLex, Brussels

COM(2007)354 final, Commission of the European Communities, Green Paper from the Commission to the Council, the European Parliament, the European Economic and Social Committee and the Committee of the Regions, Adapting to climate change in Europe - options for EU action, Commission of the European Communities, EUR-Lex, Brussels

$\operatorname{COM}(2008) 875$ final, Report from the Commission to the Council and the European Parliament. Follow up Report to the Communication on water scarcity and droughts in the European Union, Commission of the European Communities, EUR-Lex, Brussels

COM(2009)147 final, White Paper. Adapting to climate change: Towards a European framework for actions, Commission of the European Communities, Commission of the European Communities, EUR-Lex, Brussels 
$\operatorname{COM}(2011) 133$, Report from the Commission to the European Parliament and the Council to the Communication on water scarcity and droughts in the European Union, Commission of the European Communities, EUR-Lex, Brussels

Dąbrowska-Zielińska K., Kowalik W., Budzyńska M., Małek L., Bochenek Z., 2011, Assessment of evapotranspiration and soil moisture for Biebrza wetlands using thermal remote sensing and in-situ data, [in:] Remote Sensing and Geoinformation not only for Scientific Cooperation, L. Halounová (ed.), EARSeL, 281-288

Eitzinger J., Marinkovic D., Hösch J., 2003, Sensitivity of different evapotranspiration calculation methods in different crop-weather models, Integrated Assessment and Decision Support, [in:] Proceedings of the $1^{\text {st }}$ Biennial Meeting of the iEMSs, vol. 2, 395-400, http://www.iemss.org/iemss2002/ (data access 06.07.2016)

EUMETSAT, 2010, SAF for Land Surface Analysis (LSA-SAF), Algorithm Theoretical Basis Document, Meteosat Second Generation Evapotranspiration (MET) Product, Daily MET (DMET) Product, EUMETSAT LSA-SAF

EUMETSAT, 2011, Algorithm Theoretical Baseline Document (ATBD) for product H14-SM-DAS-2 Soil Wetness Index in the roots region, EUMETSAT Satellite Application Facility on Support to Operational Hydrology and Water Management, 41 pp., http://hsaf.meteoam.it/documents/ATDD/ SAF_HSAF_ATBD-14_0_2.pdf (data access 06.07.2016)

Ghilain N., Arboleda A., Sepulcre-Cantò G., Batelaan O., Ardö

J., Gellens-Meulenberghs F., 2011. Improving evapotranspiration in land surface models by using biophysical parameters derived from MSG/SEVIRI satellite, Hydrology and Earth System Sciences. Discussion, 8 (5), 9113-9171, DOI: 10.5194/hessd-8-9113-2011.

IPCC, 2007, Climate Change 2007: Synthesis Report. Contribution of Working Groups I, II and III to the Fourth Assessment Report of the Intergovernmental Panel on Climate Change, R.K. Pachauri, A. Reisinger (eds.), IPCC, Geneva, Switzerland, $104 \mathrm{pp}$.

Irmak S., Evapotraspiration, http://watercenter.unl.edu/downloads/ ResearchInBrief/IrmakSuatET.pdf (data access 06.07.2016)

Irmak S., Haman D.Z., 2003, Evapotranspiration: Potential or reference? Institute of Food and Agricultural Sciences, IFAS, University of Florida, Extension Publication No: ABE343 (AE256), http://edis.ifas.ufl.edu/pdffiles/AE/AE25600.pdf (data access 06.07.2016)

Kasperska-Wołowicz W., Łabędzki L., 2004, A comparison of reference evapotranspiration according do Penman and Penman-Monteith in various regions of Poland, (in Polish), Woda-Środowisko-Obszary Wiejskie, 4 (2a) (11), 123-136

Keller T., Gellens-Meulenberghs F., Portmann F., Hanton P., Debal F., Arboleda A., 2002, Soil moisture and evapotranspiration Land SAF products, [in:] Proceedings of the 2002
EUMETSAT LSA SAF Workshop, Lisbon, Portugal, 8 pp., http://oiswww.eumetsat.org/WEBOPS/iotm/iotm/20050908 _moisture/keller.pdf (data access 06.07.2016)

Kępińska-Kasprzak M., 2013, Hydrological droughts and their impact on water management in Poland, Ph.D. Thesis, IMGW-PIB, Warsaw, 195 pp.

Kępińska-Kasprzak M., Struzik P., 2011, Evapotranspiration as a part of water balance - comparison of ground and satellite measurements, presentation on COST Action 734 Final Conference: International Conference on current knowledge of Climate Change Impacts on Agriculture and Forestry in Europe, Topolcianki, http://www.cost734.eu/reports-andpresentations (data access 06.07.2016)

Kożuchowski K., Żmudzka E., 2001, Warming in Poland: the range and seasonality of changes in air temperature in the second half of the 20th century, (in Polish), Przegląd Geofizyczny, 46 (1-2), 81-90

Kundzewicz Z., Kowalczak P., 2008, Changes of the climate and their consequences, (in Polish), Zmiany klimatu i ich skutki. Kurpisz S.A., Poznań, 214 pp.

Kuźniar A., 2010, The spatial distribution of agricultural-climatic water balance in the upper Vistula River basin designated by applying the FAO-56 Penman-Monteith method, (in Polish), Woda-Środowisko-Obszary Wiejskie, Rozprawy naukowe i monografie, 28, 103 pp.

Lechnio J., 2005, Hydrological conditions of substance cycle in variant landscape systems, [in:] The problems of lowland landscape systems functioning, J. Lechnio, A. Richling (eds.), Warsaw University, Warsaw, 95-126

Łabędzki L., 2006, Agricultural droughts. An outline of problems and methods of monitoring and classification, WodaŚrodowisko-Obszary Wiejskie, Rozprawy naukowe i monografie, 17, $107 \mathrm{pp}$.

Masson V., Champeaux J.L., Chauvin F., Meriguet C., Lacaze R.A., 2003, Global database of land surface parameters at $1-\mathrm{km}$ resolution in meteorological and climate models, Journal of Climate, 16 (9), 1261-1282, DOI: 10.1175/1520-044216.9.1261

Michalska B., 2010, The tendencies of air temperature changes in Poland, [in:] International Conference BIOKLIMA 2010, Praga, Czech Republic, 79-80

Mu Q., Zhao M., Running S.W., 2013, MODIS Global Terrestrial Evapotranspiration (ET) Product (NASA MOD16A2/ A3), Algorithm Theoretical Basis Document, Collection 5, NASA, Washington, DC, USA, 66 pp., http://www.ntsg.umt. edu/sites/ntsg.umt.edu/files/MOD16_ATBD.pdf (data access 06.07.2016)

UN, 1994, United Nations Convention to Combat Desertification in Countries Experiencing Serious Drought and/or Desertification, Particularly in Africa, http://www.unced.int/en/about-theconvention/Pages/Text-overview.aspx (data access 06.07.2016) 
Żmudzka E., 2004, Climatic background of the agricultural production in Poland in the second half of the $20^{\text {th }}$ century, (in Polish), Acta Agrophysica, 3, 399-408 
